\title{
DIABETIC NEUROPATHIC PAIN
}

\author{
Reza Rachmantoko ${ }^{1}$, Zamroni Afif ${ }^{2}$, Dessika Rahmawati ${ }^{2}$, Rodhiyan Rakhmatiar ${ }^{2}$, Shahdevi Nandar Kurniawan ${ }^{2}$ \\ ${ }^{l}$ Doctor Profession Study Program, Medical Faculty, Brawijaya University, Saiful Anwar General Hospital, Malang, Indonesia. \\ ${ }^{2}$ Neurology Department, Medical Faculty, Brawijaya University, Saiful Anwar General Hospital, Malang, Indonesia.
}

Correspondence : shahdevinandar@ub.ac.id

\begin{abstract}
Diabetic Neuropathy is the most common complication from diabetes, which experienced in almost $90 \%$ diabetes patient. Evenly pain is one of the most common symptoms of diabetic neuropathic, but the pathophysiology mechanism of pain is not clearly known. The hyptosesis of toxicity of hyperglycemia on development of pain complication has been widely accepted globally, but there is other proposed hypothesis. Basic concept in management of painful diabetic neuropathic is exclusion of the other cause of painful peripheral neuropathy, improving glycemic control for prophylaxis therapy and medication use for alleviating pain. The first choice drug of therapy for alleviating pain are anticonvulsant, like pregabalin and gabapentin, and antidepressant, mainly that work on inhibiting serotonine and noradrenaline reuptake. In conclusion, the better understanding of painful diabetic neuropathic underlying mechanism can help to find a better management that improving the guideline quality in optimalizing pain control.
\end{abstract}

Keyword : Diabetes, neuropathic pain, hyperglychemia, anticonvulsant, antidepressant.

\section{PENDAHULUAN}

Menurut data dari International Diabetes Federation, 382 juta orang didunia menderita diabetes, salah satu penyebab utama dari neuropati. Polineuropati distal simetris (PNDS) merupakan bentuk klinis tersering dari diabetik neuropatik, yang terjadi pada lebih dari $90 \%$ pasien (1). Secara umum, PNDS mengenai jari kaki dan kaki bagian distal, namun perlahan berkembang secara proksimal melibatkan tungkai dan kaki seperti kaus kaki. Kondisi ini juga dikarakterisasi dengan kehilangan nerve fiber yang progresif baik dari divisi somatik maupun otonom. Ulserasi pada kaki dan neuropati yang nyeri merupakan komplikasi klinis utama dari PNDS, berkaitan dengan tingginya morbiditas serta mortalitas. Seringnya pasien mencari bantuan tenaga medis hanya ketika muncul nyeri, gejala yang terjadi pada $10 \%$ hingga $26 \%$ dari populasi (2).

\section{DEFINISI}

Diabetes melitus adalah sindrom yang ditandai oleh bermacam presentasi klinis dan komplikasi. Salah satunya yakni komplikasi mikrovaskuler kronis, diabetik neuropatik (3).

Diabetik neuropatik adalah entitas heterogenik, yang meliputi kondisi disfungsi sensorimotor perifer dan saraf otonom. Walau diabetik neuropatik mungkin bersifat asimtomatik, namun dapat pula terjadi dengan diiringi nyeri. Kondisi diabetik neuropatik semacam itu disebut dengan nyeri diabetik neuropatik. Gejala dari nyeri diabetik neuropatik dideskripsikan bermacam-macam, yaitu termasuk rasa terbakar yang intermiten atau kontinyu, tertusuk, kesemutan, dan mati rasa, sensasi panas, dingin, atau gatal. Gejala berkembang dalam distribusi distal ke proksimal, umumnya dimulai dari kaki (4). Diabetik neuropatik merupakan diagnosis pengecualian, dan diagnosis diabetik neuropatik menyiratkan penyebab lain dari neuropati telah dikecualikan. Penyebab umum neuropati yang harus disingkirkan sebelum diagnosis DN dibuat termasuk alkohol, defisiensi vitamin B12, kemoterapi neurotoksik, hipotiroidisme, penyakit ginjal, malignansi, infeksi seperti HIV, chronic inflammatory demyelinating neuropathy, neuropati turunan, dan vaskulitis (5).

\section{EPIDEMIOLOGI}

Nyeri neuropatik berdampak besar pada kualitas hidup pasien, terutama dengan menyebabkan gangguan yang cukup besar pada tidur, aktivitas sehari-hari, dan kenikmatan hidup. Nyeri neuropatik kronis terjadi pada 13-26\% pasien diabetes. Dalam sebuah survei terbaru dari Augsburg, Jerman, prevalensi polineuropati yang menyakitkan ditemukan $13,3 \%$ pada subjek diabetes, $8,7 \%$ pada individu dengan gangguan toleransi glukosa, 4,2\% pada individu dengan gangguan glukosa puasa, dan $1,2 \%$ pada individu dengan toleransi glukosa normal. Faktor independen yang secara signifikan terkait dengan nyeri diabetik neuropatik (DPN) adalah usia, berat badan, dan penyakit arteri perifer (6).

\section{Article History:}

Received: 25 Januari 2021; Accepted:17 Februari, 2021; Published: 1 Maret, 2021

\section{Cite As:}

Rachmantoko R, Afif Z, Rahmawati D, Rakhmatiar R, Kurniawan SN. Diabetic neuropathic pain. Journal of Pain, Vertigo and Headache; 2021.1:8-12 


\section{MANIFESTASI KLINIK}

Pasien dengan neuropati diabetik yang menyakitkan secara khas datang dengan keluhan kesemutan, mati rasa, rasa terbakar, jenis nyeri seperti menusuk yang menyiksa, kadangkadang tidak dapat mereda dan mungkin berhubungan dengan paresthesia dan hiperestesia ditambah dengan rasa sakit yang dalam di kaki atau tangan. Kondisi ini biasanya merupakan jenis neuropati sensorimotor distal simetris. Karakteristik klinis lainnya adalah karena keterlibatan dari nerve fiber kecil dan besar (sensorimotor campuran). Pada awalnya, bagian paling distal dari ekstremitas yang terkena, menyebabkan hilangnya sensorik dengan bentukan glove and stocking yang khas, yang menunjukkan keterlibatan serabut saraf terpanjang. Hilangnya sensorik diikuti dengan keterlibatan tungkai atas bagian distal, aspek anterior batang tubuh, dan kemudian puncak kepala. Secara keseluruhan terjadi gangguan sensasi raba ringan, kepekaan terhadap tekanan dan getaran, serta proprioseptif sendi. Gejala biasanya muncul pada malam hari dan secara keseluruhan mempengaruhi kualitas hidup individu termasuk mobilitas, pekerjaan, tidur, suasana hati, harga diri, rekreasi dan aktivitas sosial (7).

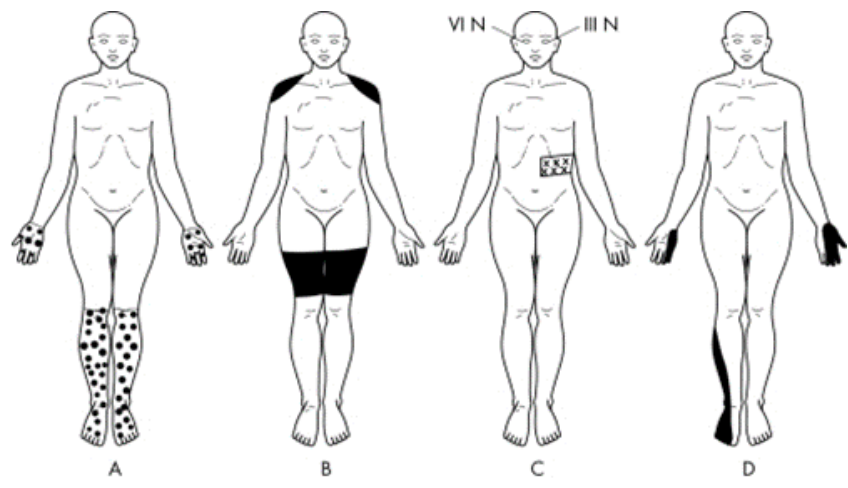

Gambar 1. Diagram skematik bentuk diabetik neuropatik. A) neuropati perifer distal simetris, B) neuropati proksimal, C) neuropati trunkus dan kranial, dan D) mononeuropati multipleks (18).

\section{FAKTOR RESIKO}

Durasi diabetes dan kadar hemoglobin A1c (HbA1c) (pengukuran glikasi hemoglobin sebagai pengganti rata-rata kadar glukosa harian) adalah prediktor utama diabetik neuropatik (8). Kedua prediktor ini umumnya diasosiasikan dengan faktor metabolik lain yang terkait dengan diabetik neuropatik, terutama pada diabetes tipe 2, seperti resistensi insulin dan hipertensi. Obesitas sering terjadi pada pasien dengan neuropati dalam penelitian berbasis populasi di banyak negara, termasuk Amerika Serikat, Denmark, Cina, dan Belanda (9).

Tidak berkaitan dengan tingkat HbA1c, jumlah komponen sindrom metabolik, seperti hipertrigliseridemia, hipertensi, obesitas, dan kadar lipoprotein densitas tinggi rendah (HDL), secara konsisten dikaitkan dengan neuropati diabetik pada pasien dengan diabetes tipe 2 dan dalam beberapa kelompok diabetes tipe 1. Faktor risiko independen lain untuk perkembangan diabetik neuropatik termasuk merokok, penyalahgunaan alkohol, dan usia yang lebih tua (10).

Beberapa gen dapat berkaitan dengan kondisi diabetik neuropatik, tetapi sejauh ini hanya ACE (angiotensinconverting enzyme) dan MTHFR (methylenetetrahydrofolate reductase) yang polimorfisme telah dipelajari dalam banyak populasi termasuk kelompok besar. Namun dibutuhkan lebih banyak penelitian untuk lebih memahami peran genetika dalam perkembangan diabetik neuropatik (10).

\section{FISIOPATOLOGI}

Walau sudah didapatkan perkembangan yang besar dalam memahami mekanisme patofisiologi dari komplikasi diabetes namun sejauh ini masih belum ada hipotesa yang dapat menerangkan mengapa pada satu kelompok dapat mengalami bentuk yang menyakitkan dan pada kelompok lain tidak. Berikut merupakan beberapa mekanisme patofisiologi yang dipercaya memerantarai kondisi nyeri pada diabetik neuropatik (3).

\section{Hiperaktivitas Polyol Pathway}

Gangguan metabolik merupakan penyebab utama diabetik neuropatik. Hiperglikemia, bertanggung jawab atas peningkatan aktivitas jalur polyol. Hal ini menyebabkan adanya peningkatan turnover dari kofaktor seperti NADPH dan $\mathrm{NAD}^{+}$, yang berujung pada penurunan dari reduksi dan regenerasi glutation. Deplesi glutation dapat menjadi penyebab utama dari stres oksidatif dan akumulasi toksik (3).

\section{Stres Oksidatif dan Nitrosatif}

Seperti yang sudah disebutkan bahwa stres oksidatif dapat disebabkan hiperaktivitas polyol, adapun stres oksidatif juga dapat diinisiasi oleh autooksidasi dari glukosa dan metabolit, meningkatkan formasi dari AGE (advanced glycation end product), peningkatan ekspresi dari reseptor AGE dan ligand aktivasinya, perubahan fungsi mitokondrial, aktivasi dari isoform PKC dan overaktivitas dari jalur hexosamin. Selain itu ada juga studi yang menyebutkan bahwa peningkatan pembentukan radikal bebas akibat metabolisme glukosa dapat juga menjadi faktor utama diabetik neuropatik (3).

\section{Perubahan Mikrovaskular}

Adanya perubahan mikrovaskular menyebabkan perfusi perifer yang menurun. Hal ini menyebabkan iskemia syaraf, disebabkan oleh peningkatan ketebalan dinding dan hyalinisasi basal lamina pembuluh darah (3).

\section{Channel Sprouting}

Adanya gangguan aksi potensial dapat dihasilkan oleh nerve end yang rusak, yang diinterpretasikan oleh CNS sebagai nyeri atau disestesia. Beberapa channel ion juga dapat mengalami gangguan berupa upregulasi seperti Nav channel, $\mathrm{Na}$ channel, Calcium channel, Kv channel (3).

\section{Aktivasi Mikroglia}

Adanya aktivasi mikroglia sebagai efek jangka pendek dari peripheral nerve injury bertanggung jawab atas produksi dari beberapa mediator inflamasi seperti sitokin, kemokin dan substansi sitotoksik (NO dan radikal bebas) (3).

\section{Sensitisasi Sentral}

Ketika pasien mengalami nyeri diabetik neuropatik, aferen primer tersensitisasi, menginduksi hiperaktivitas cornu dorsalis dan perubahan neuroplastik pada neuron sensorik sentral sehingga terjadi gangguan proses interpretasi nyeri pada CNS (3). 


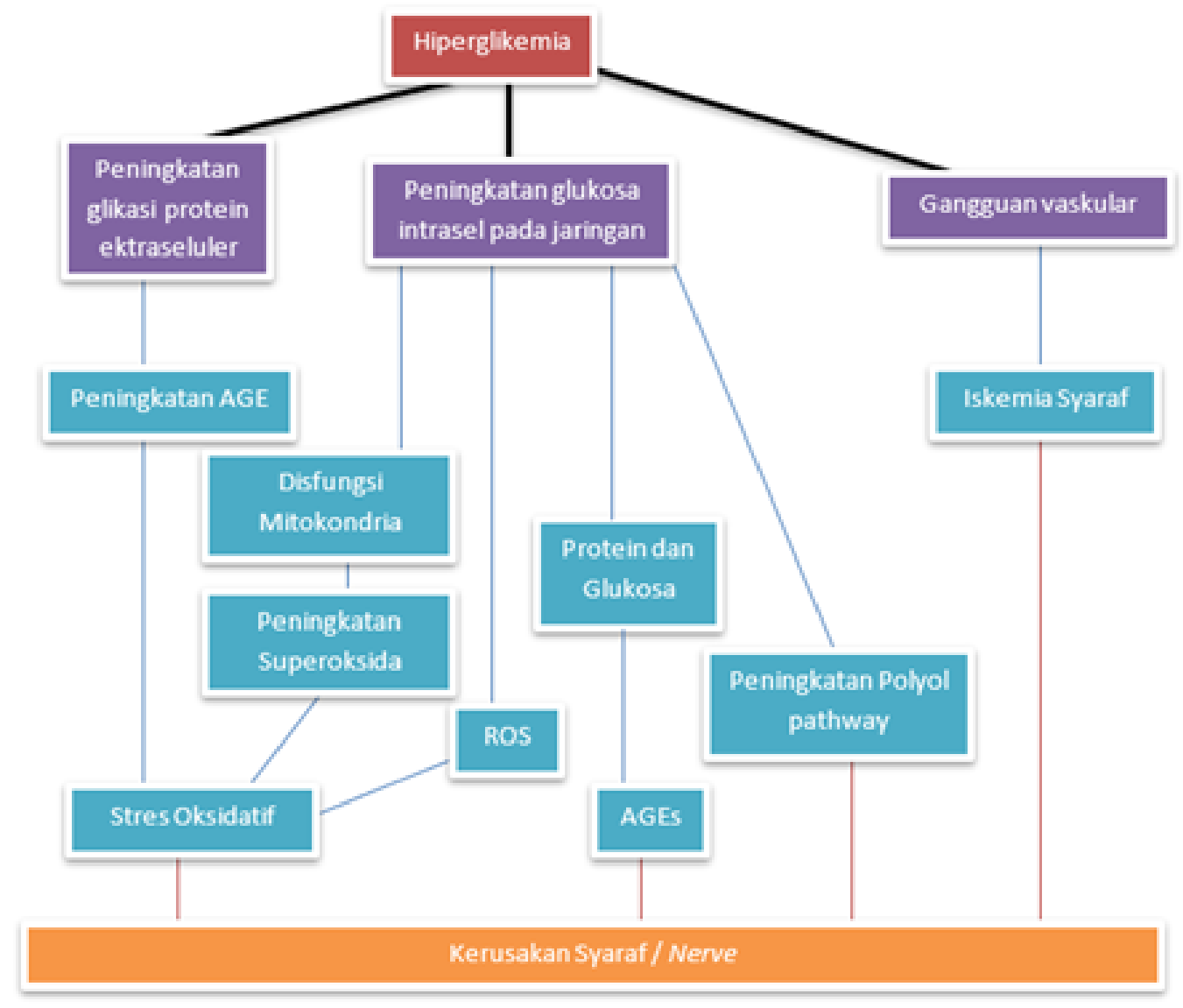

Gambar 2. Patofisiologi Diabetik Neuropatik (3).

\section{Plastisitas Otak}

Teori yang lain menyatakan bahwa ada perubahan fungsional dari area pemroses nyeri pada CNS selain korda spinalis. Hal ini dapat berkaitan dengan perubahan pada thalamus, korteks dan rostroventromedial medulla (3).

\section{DIAGNOSIS}

Untuk diagnosis diabetik neuropatik, pemeriksaan bedsite harus mencakup penilaian kekuatan otot, sensasi tusuk jarum, posisi sendi, sentuhan, dan suhu (11). Tes getaran sebaiknya dilakukan dengan garpu tala berukuran $128 \mathrm{~Hz}$. Untuk sensasi sentuhan, direkomendasikan dengan filamen mono 1 g. Pemeriksaan sensorik harus dilakukan pada tangan dan kaki secara bilateral. Pada usia tua (> 70 tahun) getaran dan refleks pergelangan kaki dapat berkurang secara normal dan dianggap abnormal jika tidak ada daripada berkurang pada pasien dengan diabetik neuropatik. Tes sensorik kuantitatif dapat digunakan sebagai tes tambahan tetapi tidak direkomendasikan untuk praktik klinis rutin. Tes fungsi otonom yang biasa digunakan untuk diabetes mellitus didasarkan pada tekanan darah dan respons detak jantung terhadap serangkaian manuver. Tes khusus digunakan untuk mengevaluasi fungsi gastrointestinal, genitourinari, sudomotor, dan aliran darah kulit tepi (12). Biopsi saraf mungkin berguna untuk menyingkirkan penyebab lain dari neuropati. Biopsi kulit telah digunakan ketika semua tindakan lain negatif dalam diagnosis neuropati serat kecil untuk kuantifikasi produk gen protein, yang merupakan penanda panaksonal. Diabetes sebagai penyebab neuropati didiagnosis dengan mengesampingkan penyebab lain pada pasien yang hadir dengan kaki yang nyeri dan memiliki gangguan tes toleransi glukosa. Baru baru ini penggunaan mikroskopi kornea confocal dalam penilaian polineuropati diabetik telah dilaporkan. Dalam mikroskop confocal, kornea dipindai dan gambar dari lapisan Bowman yang mengandung pleksus saraf yang kaya diperiksa untuk dinilai kepadatan, panjang nerve fiber, dan kepadatan cabang. Parameter ini berkurang secara signifikan dalam diabetik neuropatik dan berkorelasi dengan tingkat keparahan neuropati. Karena sifatnya yang noninvasif, mikroskop confocal mungkin memiliki potensi besar dalam menilai struktur saraf in vivo tanpa perlu biopsi saraf (13).

\section{TATALAKSANA}

Nyeri diabetik neuropatik terus menjadi tantangan dalam terapeutik dikarenakan patofisiologinya belum sepenuhnya dipahami dan hasil pereda nyeri masih belum memuaskan. Perawatan farmakologis, dengan pengecualian yang ditargetkan untuk kontrol glikemik, bersifat simtomatik, tidak terfokus pada mekanisme patofisiologis, dibatasi oleh efek samping dan oleh perkembangan dari toleransi.

Berbagai macam obat, digunakan sendiri atau dalam kombinasi, telah terbukti secara signifikan mengurangi nyeri neuropatik dibandingkan dengan plasebo dalam uji coba terkontrol secara acak, tetapi pereda nyeri tetap tidak memadai untuk kebanyakan pasien. Secara umum, dalam uji 
klinis, pengobatan dianggap berhasil jika pasien memperoleh $50 \%$ pengurangan tingkat nyeri diiringi dengan beberapa efek menguntungkan tambahan pada tidur, kelelahan, depresi dan kualitas hidup. Dengan demikian, manajemen kondisi ini pada dasarnya terdiri dari eksklusi penyebab lain dari neuropati perifer yang menyakitkan, meningkatkan kontrol glikemik sebagai terapi profilaksis dan menggunakan obatobatan untuk mengurangi rasa sakit (14-16).

Terlepas dari pendekatan multimodal dan multidisiplin untuk pengobatan, jalur utama didasarkan pada farmakologis. Tiga agen berbeda memiliki persetujuan peraturan di Amerika Serikat untuk pengobatan DNP: pregabalin, duloxetine dan tapentadol. Namun, karena pereda nyeri masih kurang optimal dan menantang bagi dokter, obat-obatan dari berbagai kelas farmakologis telah digunakan dan beberapa di antaranya seperti capsaicin krim topikal, patch lidokain, asam alpha lipoic, spray isosorbid dinitrat, serta opioid (17-20).

Tabel 1. Medikasi rekomendasi untuk terapi nyeri diabetik neuropati perifer (16).

\begin{tabular}{|c|c|c|}
\hline Kelas & Obat & Dosis Rekomendasi \\
\hline $\begin{array}{l}\text { Antidepresan } \\
\text { Trisiklik }\end{array}$ & Amitriptilin & $10-100 \mathrm{mg}$ sebelum tidur \\
\hline & $\begin{array}{l}\text { Nortriptilin } \\
\text { Desipramin }\end{array}$ & $\begin{array}{l}25-150 \mathrm{mg} \text { sebelum tidur } \\
25-150 \mathrm{mg} \text { sebelum tidur }\end{array}$ \\
\hline Antikonvulsan & $\begin{array}{l}\text { Pregabalin } \\
\text { Gabapentin }\end{array}$ & $\begin{array}{l}150-600 \mathrm{mg} \text { perhari dibagi } \\
\text { menjadi } 2 / 3 \text { dosis } \\
300-1200 \mathrm{mg} 3 \text { kali sehari }\end{array}$ \\
\hline SSRI atau SNRI & $\begin{array}{l}\text { Venlafaxin } \\
\text { Duloxetin }\end{array}$ & $\begin{array}{l}\text { 150-215 mg per hari } \\
60-120 \mathrm{mg} \text { per hari }\end{array}$ \\
\hline Opioid & $\begin{array}{l}\text { Morfin } \\
\text { Tramadol } \\
\end{array}$ & $\begin{array}{l}15-120 \mathrm{mg} \text { per hari } \\
200-400 \mathrm{mg} \text { per hari }\end{array}$ \\
\hline Agen Topikal & $\begin{array}{l}\text { Krim } \\
\text { kapsaikin } \\
\text { Lidokaine } \\
\text { patch 5\% } \\
\end{array}$ & $\begin{array}{l}0.075 \% 4 \text { kali sehari } \\
\text { Bisa hingga } 3 \text { kali perhari }\end{array}$ \\
\hline
\end{tabular}

Terapi non farmako dinilai dapat meningkatkan kualitas hidup pasien dengan nyeri diabetik neuropatik. Terapi yang dianjurkan meliputi stimulasi elektrik, latihan aerobik, dan terapi ladang magnetik. Hasil dari terapi bervariasi diantara studi. Beberapa studi mengatakan adanya efek yang signifikan dalam mengurangi tingkat nyeri. Edukasi pasien juga penting dalam meningkatkan kontrol glikemik pasien dan menghindari komplikasi terlambat dari diabetik neuropatik (16).

\section{KESIMPULAN}

Nyeri diabetik neuropatik sering terjadi dan dikaitkan dengan penurunan kualitas hidup pasien diabetes yang signifikan. Meskipun memiliki beban yang tinggi, penyakit ini tetap kurang terdiagnosis (underdiagnosed) dan kurang terawat (undertreated). Pengobatan yang memperbaiki saraf belum ditemukan dan diterjemahkan ke dalam uji klinis dan akhirnya disetujui menjadi terapi dalam praktik klinis. Sementara sejumlah opsi perawatan tersedia dan berbagai pedoman dan algoritme telah dirumuskan, hasilnya kurang memuaskan. Berbagai pengobatan simptomatik telah diusulkan untuk menangani nyeri neuropatik tetapi hanya sedikit yang terbukti efektif, dengan hanya tiga obat yang saat ini disetujui FDA untuk nyeri diabetik neuropatik. Penelitian di masa depan harus menetapkan kombinasi obat yang paling manjur, dan sebagai tambahan dalam eksploitasi mekanisme baru dan menyelidiki obat baru untuk pengobatan nyeri pada diabetik neuropati.

\section{ACKNOWLEDGMENT}

Tidak ada.

\section{CONFLICT OF INTEREST}

Tidak ada.

\section{REFERENCES}

1. Atlas D. International Diabetes Federation. IDF Diabetes Atlas, 7th edn. Brussels, Belgium: International Diabetes Federation; 2015

2. Tesfaye S, Boulton AJ, \& Dickenson AH. Mechanisms and management of diabetic painful distal symmetrical polyneuropathy. Diabetes Care; 2013. 36(9):2456-2465. DOI: $10.2337 / \mathrm{dc} 12-1964$

3. Schreiber AK, Nones CF, Reis RC, Chichorro JG \& Cunha JM. Diabetic neuropathic pain: Physiopathology and treatment. World Journal of Diabetes; 2015. 6(3):432-444.

DOI: https://doi.org/10.4239/wjd.v6.i3.432

4. Richard PA, Daniel LP, William GO. Restless legs syndrome/Willis-Ekbom disease diagnostic criteria: Updated International Restless Legs Syndrome Study Group (IRLSSG) consensus criteria - history, rationale, description, and significance, Sleep Medicine; 2014. 15(8.2014):860-873. ISSN 1389-9457.

DOI: https://doi.org/10.1016/j.sleep.2014.03.025.

5. Kalra S \& Gupta A. Diabetic painful neuropathy and restless legs syndrome in diabetes; 2018.

DOI: https://doi.org/10.1007/s13300-018-0376-6

6. Pop-Busui R, Boulton AJ, Feldman EL, Bril V, Freeman R, Malik RA, \& Ziegler D. Diabetic neuropathy: A position statement by the American Diabetes Association. Diabetes Care; 2017. 40(1):136154. DOI: https://doi.org/10.2337/dc16-2042

7. Juster-Switlyk K, \& Smith AG. Updates in diabetic peripheral neuropathy. F1000Research; 2016.5.

DOI: 10.12688/f1000research.7898.1

8. Feldman EL, Callaghan BC, Pop-Busui R, Zochodne DW, Wright DE, Bennett DL, \& Viswanathan V. Diabetic neuropathy. Nature Reviews Disease Primers; 2019. 5(1):1-18. DOI :10.1038/s41572-019-0097-9.

9. Hanewinckel R, Drenthen J, Ligthart S, Dehghan A, Franco OH, Hofman A, ... \& van Doorn PA. Metabolic syndrome is related to polyneuropathy and impaired peripheral nerve function: A prospective populationbased cohort study. Journal of Neurology, Neurosurgery \& Psychiatry; 2016. 87(12):1336-1342.

DOI: http://dx.doi.org/10.1136/jnnp-2016-314171

10. Callaghan BC, Price RS \& Feldman EL. Distal symmetric polyneuropathy: A review. JAMA; 2015. 314:2172-218. DOI:10.1001/jama.2015.13611

11. Javed S, Petropoulos IN, Alam U, \& Malik RA. Treatment of painful diabetic neuropathy. Therapeutic Advances In Chronic Disease; 2015. 6(1), 15-28.

DOI: $\quad$ https://doi.org/10.1177/2040622314552071 
12. Shillo P, Sloan G, Greig M, Hunt L, Selvarajah D, Elliott J \& Tesfaye S. Painful and painless diabetic neuropathies: What is the difference? Current Diabetes Reports; 2019. 19(6):32.

DOI: https://doi.org/10.1007/s11892-019-1150-5

13. Petropoulos IN, Ponirakis G, Khan A, Almuhannadi H, Gad H, Malik RA. Diagnosing diabetic neuropathy: Something old, something new. Diabetes \& Metabolism Journal; 2018 Aug;42(4):255-69. DOI: https://doi.org/10.4093/dmj.2018.0056

14. Iqbal Z, Azmi S, Yadav R, Ferdousi M, Kumar M, Cuthbertson DJ, Lim J, Malik RA, Alam U. Diabetic peripheral neuropathy: Epidemiology, diagnosis, and pharmacotherapy. Clinical Therapeutics; 2018. Jun;40(6):828-49.

DOI: https://doi.org/10.1016/j.clinthera.2018.04.001

15. Yorek M, Malik RA, Calcutt NA, Vinik A, Yagihashi S. Diabetic neuropathy: New insights to early diagnosis and treatments. Journal of Diabetes Research; 2018 DOI: https://doi.org/10.1155/2018/5378439

16. Hershey DS. Diabetic peripheral neuropathy: Evaluation and management. The Journal for Nurse Practitioners; 2017. Mar 1;13(3):199-204. DOI: http://dx.doi.org/ 10.1016/j.nurpra.2016.08.034

17. Bansal V, Kalita J, Misra UK. Diabetic neuropathy. Postgraduate Medical Journal; 2006 Feb 1;82(964):95100. DOI: $10.1136 /$ pgmj.2005.036137

18. Hanik H. Carbamazepine as a pain treatment of trigeminal neuralgia. Journal of Pain, Headache and Vertigo (JPHV); 2020. 1(2):37-41.

DOI : https://doi.org/10.21776/ub.jphv.2020.001.02.4

19. Badrul M, Widodo MS, Zamroni A, Shahdevi NK. Radiofrequency as pain interventional therapy in neurology. Journal of Pain, Headache and Vertigo (JPHV); 2020. 1(2):31-36.

DOI : https://doi.org/10.21776/ub.jphv.2020.001.02.3 